\title{
Influence of Long Chain Free Fatty Acids on the Thermal Resistance Reduction of Bacterial Spores
}

\author{
Brice Mvou Lekogo, Louis Coroller, Pierre Mafart, Ivan Leguerinel ${ }^{*}$
}

Laboratoire Universitaire de Biodiversité et Ecologie Microbienne, Université de Brest, UEB, Quimper, France.

Email: "guerinel@univ-brest.fr

Received May $6^{\text {th }}, 2013$; revised June $6^{\text {th }}, 2013$; accepted June $13^{\text {th }}, 2013$

Copyright (C) 2013 Brice Mvou Lekogo et al. This is an open access article distributed under the Creative Commons Attribution License, which permits unrestricted use, distribution, and reproduction in any medium, provided the original work is properly cited.

\begin{abstract}
Aims: The objective of this study was to investigate the effect of free fatty acid length chain and unsaturated bond number on the heat resistance and recovery media of bacterial spores. Methods and results: For 6 species, bacterial spore heat resistances were estimated at different free fatty acid concentrations added to heating media or in recovery media. The addition of free fatty acids to heating media has a slight influence on the heat resistance of bacterial spores whatever the species or type of acid studied. On the contrary, the addition of free fatty acids to the recovery medium after the heat treatment greatly reduces the ability to bacterial spores to recover and form colonies. This effect varies depending on chain length, unsaturated bond number of fatty acid and on the bacterial strain studied. Conclusion: The presence of free acids in the recovery media is an additive stress which decreases the capability of injured spores to germinate and grow thereafter. Significance and impact of this study: The impact of free fatty acids presented in this study can be taken into account to reduce the thermal intensity of food sterilization in relation to their availability in food matrix.
\end{abstract}

Keywords: Free Fatty Acid; Bacterial Spores; Heat Resistance

\section{Introduction}

The reduction of heat treatment intensity of food is a major challenge in the food industry. The main reasons are the preservation of the nutritional and sensorial quailties and saving energy in the context of sustainable development. Based on the hurdle concept developed by Leistner [1], other stress factors can be considered and associated with the heat treatment, such as the presence of antimicrobial molecules in the heat-treated food. One way to diminish heat treatment is to reduce bacterial heat resistance by combining thermal stress with other stresses such as a reduction of water activities or $\mathrm{pH}$ in heating and recovery media. Some of these combined effects are known and have been modelled [2-4]. Regarding the $\mathrm{pH}$, this effect is taken into account and used by some food canning companies to optimize their sterilization heating times.

Free fatty acids are non-toxic antimicrobial molecules and are naturally present in some food such as fat liver, fish or animal fat or natural olive oil. The bactericidal effects of free fatty acids have been extensively studied

${ }^{*}$ Corresponding author. by Neiman [5] and Kabara [6] who determined the MIC of saturated and unsaturated free fatty acids for different bacterial species. The values of minimum inhibitory concentrations (MIC) of free fatty acids vary depending on the nature of the acid. They are not correlated with the length of the chain but are strongly influenced by the number of unsaturated bonds in the carbon chain in some foods, their presence in high concentrations in natural fats or oils limits or inhibits bacterial growth. Numerous studies have characterized the inhibitory effect of free fatty acids on bacteria in food. These studies have involved vegetative bacteria such as Salmonella sp [7], Staphylococcus aureus [8], Listeria monocytogenes [9], Escherichia coli $[10,11]$ or bacterial spores such as $B a$ cillus cereus [8,12], Bacillus subtilis [13], Clostridium botulinum [12,14] and Clostridium perfringens [15].

Foster and Wyne [16] showed inhibition of Clostridium botulinum germination in the presence of oleic acid. For Bacillus subtilis this inhibition is different depending on the nature of the free fatty acids and their concentration [13]. Yasuda et al. [17] showed that at equal molarity of $0.2 \mathrm{mmol} \cdot \mathrm{l}^{-1}$, the percentage of inhibition was twice as high for oleic, linoleic and linolenic unsaturated 
free fatty acids than for palmitic and stearic saturated fatty acids. These authors explain this inhibitory effect by interaction between free fatty acids and the hydrophobicity of the spore surface which blocks bacterial spore germination mechanisms and therefore bacterial growth $[13,17,18]$.

The antimicrobial activities of free fatty acids were clearly presented by Desbois and Smith [19] in a review. Different mechanisms may account for these inhibitory effects on vegetative bacteria. It appears that these molecules primarily affect the cell membranes where they are adsorbed [20,21]. The insertion of free fatty acids in the membrane disrupts the electron transport chain, inhibits reactions of oxidative phosphorylation, inhibits enzyme activities and the entry of nutrients into the cell and can cause cell lysis.

The effect of free fatty acids in germination or growth of bacterial spore has been studied. However few studies have quantified the inhibitory effect of free fatty acids associated with a food heat treatment. Studies which describe the effect of free fatty acid in germination and growth of bacterial spore after heat treatment are scarce. For various long-chain (C16-C18) free fatty acids with different unsaturation levels, Tremoulet et al. [22] observed that the increase in their concentrations in the heating treatment medium decreased the decimal reduction time of spores of Geobacillus stearothermophilus. Ababouch et al. [23] reported a decrease in the apparent heat resistance of Bacillus cereus spores when free fatty acids were added to the incubation medium. Mvou Lekogo et al. [24] have described the influence of the presence of free fatty acids in both heating and recovery media on the heat resistance of spores of Bacillus cereus and Clostridium sporogenes. A Bigelow-like equation was developed to quantify the effect of free fatty acid in these two media on the $\mathrm{D}$ values. This study was limited to four free fatty acids (palmitic, palmitoleic, stearic and oleic). These free fatty acids added to the recovery media more efficiently reduced the $\mathrm{D}$ value than when they were added to the heating media.

The aim of this study is to assess the impact of the length and degree of unsaturation of the carbon chains of free fatty acids added to heating or recovery media, on the heat resistance of spores of different bacterial species.

\section{Material and Methods}

\subsection{Microorganisms and Spore Production}

Aero-anaerobic and anaerobic species of spore forming bacteria were studied. Bacillus cereus NTCC1145, Geobacillus stearothermophilus CIP-23T, Bacillus licheniformis Bac37 isolated from dairy product and Bacillus pumilus E71 isolated from vegetables were used. Two strains of Clostridium sporogenes were studied: strain Pasteur 79.3 and strain Ad81 isolated from dairy product. These species are currently present as spoilage or pathogen bacterial spores in large food products. Spores of aero-anaerobic species were obtained as follows: cells were precultivated at $37^{\circ} \mathrm{C}$ for $24 \mathrm{~h}$ in Brain Heart Infusion (Difco). The preculture was used to inoculate nutrient agar plates (Biokar Diagnostics BK021) with $\mathrm{MnSO}_{4}$ $40 \mathrm{mg} / \mathrm{l}$ and $\mathrm{CaCl}_{2} 100 \mathrm{mg} / \mathrm{l}$ added to the surface area. The plates were incubated at $37^{\circ} \mathrm{C}$ for 5 days. The spores were then collected by scraping the surface of the agar, suspended in sterile distilled water, and washed three times by centrifugation (10,000 g for $15 \mathrm{~min}$ ) (Bioblock Scientific, model Sigma 3K30). The final suspension (about $10^{10}$ spores $/ \mathrm{ml}$ ) was finally distributed in sterile Eppendorfs micro tubes and kept at $4^{\circ} \mathrm{C}$. Clostridium sporogenes spore production was obtained by the method described by Goldoni et al. [25].

\subsection{Source and Preparation of Fatty Acids}

The free fatty acids used in this study had a carbon chain length ranging between 14 and 20 carbon atoms and had a degree of unsaturation (number of double bonds) between 0 and 3. Cis unsaturation was chosen because it is the form which is found in food. The free fatty acids used were: myristic acid (Fluka), palmitic acid (Alfa Aesar), stearic acid (Fluka), oleic acid (Alfa Aesar), linoleic acid (Acros Organics), linolenic acid (Acros Organics) and arachidonic acid (Fluka). Emulsions with different free fatty acid concentrations were obtained by mixing (Polytron $^{\circledR}$ PT-MR 2100, Kinematica AG, Switzerland) and microsonication (Branson Sonifier 250, Branson Ultrasonics, USA) in distilled water with $0.1 \%$ Tween $^{\mathrm{TM}} 80$ as a dispersant (Alfa Aesar, Strasbourg, France). The lack of influence of Tween ${ }^{\mathrm{TM}} 80$ on bacterial heat resistance was previously controlled (data not shown).

These solutions were added to nutrient broth $(10 \mathrm{~g}$ tryptone, $5 \mathrm{~g}$ meat extract, $5 \mathrm{~g}$ sodium chloride per liter of water) (Biokar Diagnostic) for heating media or nutrient broth with Bacteriological Agar $\left(15 \mathrm{~g} \cdot \mathrm{l}^{-1}\right)$ (Biokar Diagnostic) for recovery media. The concentrations of free fatty acids added to heating media were $0.8 \mathrm{mmol} \cdot l^{-1}$. In recovery media, different concentrations were added, ranging from 0 to $0.8 \mathrm{mmol} \cdot \mathrm{l}^{-1}$. After sterilization by autoclaving at $110^{\circ} \mathrm{C}$ for 45 minutes, as described by Marounek et al. [10], the $\mathrm{pH}$ was adjusted to 7.

\subsection{Heat Treatments of Spores}

Firstly, $30 \mu \mathrm{l}$ of spore suspension was diluted in $3 \mathrm{ml}$ of adjusted heating medium. $200 \mu \mathrm{l}$ (vitrex) capillary tubes were filled with $100 \mu \mathrm{l}$ of sample, sealed, and subjected to a thermal treatment in a thermostated glycerol bath for different heating times. The heat treatment was stopped 
by cooling capillary tubes in a water/ice bath. Then they were broken at both ends and their contents poured into a tube containing $9 \mathrm{ml}$ of sterile tryptone salt broth (Biokar Diagnostics) by rinsing with $1 \mathrm{ml}$ of tryptone salt broth. The viable spores were counted by duplicate plating in recovery media and incubated at $37^{\circ} \mathrm{C}$ for Bacillus cereus, Bacillus pumilus, Bacillus licheniformis strains at $37^{\circ} \mathrm{C}$ anaerobically for Clostridium sporogenes and at $55^{\circ} \mathrm{C}$ for Geobacillus stearothermophilus.

\subsection{Data Analysis}

For each condition, classical D values and their associated confidence interval were fitted by using module "nlinfit" and "nlparci" Matlab 6 1, The Mathworks. One level of concentration was studied to evaluate the influence of free fatty acid in heating media. Concerning the influence of free fatty acid in recovery media, for each fatty acid studied, D values were estimated for different concentrations ranging from $0 \mathrm{mmol} \cdot l^{-1}$ to $0.8 \mathrm{mmol} \cdot l^{-1}$, added to the recovery media.

The influence of the free fatty acid concentration in recovery media on the $\mathrm{D}$ values can be modelled by a simple Bigelow-like model (Equation (1)) [23].

$$
\log \mathrm{D}=\log \mathrm{D}^{*}-\frac{[\mathrm{acid}]}{\mathrm{Z}_{\mathrm{FFA}}^{\prime}}
$$

In this model, $\mathrm{z}_{\mathrm{FFA}}^{\prime}$ values represent the increase in free fatty acid concentration in the recovery media, which led to a 10 -fold reduction in the $\mathrm{D}$ value ( $\mathrm{D}^{*}$ corresponds to the $\mathrm{D}$ values without free fatty acids in the recovery media). This parameter quantifies the influence of fatty acid concentration in the recovery media on the heat resistance of the bacterial spores. The sensitivity parameters of the models $z_{\mathrm{FFA}}^{\prime}$ and their confidence interval were fitted to experimental values using the module "nlinfit" and "nlparci" Matlab 6 1, (Mathworks, Meudon France). This model and its associated parameter values have been established for FFA concentrations in recovery media ranging from $0 \mathrm{mmol} \cdot \mathrm{l}^{-1}$ to 0.8 $\mathrm{mmol} \cdot \mathrm{l}^{-1}$.

\section{Results}

Oleic acid is a major free fatty acid present in oils and fats. The impact of this acid added to the heating and recovery media on the heat resistance (D values) of different species of bacterial spores was studied and is presented in Tables 1 and $\mathbf{2}$. It can be seen that the presence of $0.8 \mathrm{mmol} \cdot \mathrm{l}^{-1}$ of oleic acid in the treatment medium slightly reduces the heat resistance of bacterial spores. The addition of $0.8 \mathrm{mmol} \cdot \mathrm{l}^{-1}$ of oleic acid in heating media reduced the heat resistance of the strain of Clostridium sporogenes Pasteur 79.3 to 0.88 fold while it de- creased the heat resistance to 0.55 fold for the Geobacillus stearothermophilus strain CIP-23T studied.

The presence of oleic acid in the recovery medium clearly affects the apparent heat resistance of bacterial spores (Figure 1 and Table 2). This influence varies according to the strain studied, whereby a lower value of the $z_{\mathrm{FFA}}^{\prime}$ parameter indicates a higher sensitivity. Strains can be very sensitive, such as the strain of Clostridium sporogenes with a $z_{\text {oleic }}^{\prime}$ value of $0.31 \mathrm{mmol} \cdot l^{-1}$. Other strains are less sensitive, such as Bacillus licheniformis with a $z_{\text {oleic }}^{\prime}$ value of $3.16 \mathrm{mmol} \cdot \mathrm{l}^{-1}$.

The nature of the free fatty acid also modifies its effect on the heat resistance of bacterial spores. The influence of the length of the carbon chain of saturated free fatty acids on the heat resistance of Bacillus cereus ATCC 11145 strain was studied. Tables $\mathbf{3}$ and $\mathbf{4}$ present bacterial heat resistance and sensitivity according to the free

Table 1. D values (minutes) determined for bacterial spores of different species for $0.0 \mathrm{mmol} \cdot \mathrm{I}^{-1}$ and $0.8 \mathrm{mmol} \cdot \mathrm{I}^{-1}$ of oleic acid added to heating media.

\begin{tabular}{cccc}
\hline & Heating $\mathrm{T}^{\circ} \mathrm{C}$ & $0.0 \mathrm{mmol} \cdot 1^{-1}$ & $0.8 \mathrm{mmol} \cdot 1^{-1}$ \\
\hline $\begin{array}{c}\text { B. cereus ATCC } \\
11145\end{array}$ & $100^{\circ} \mathrm{C}$ & $6.74 \pm 0.20^{*}$ & $4.77 \pm 0.28$ \\
$\begin{array}{c}\text { B. pumilus } \text { E71 } \\
\text { B. licheniformis } \\
\text { BAC37 }\end{array}$ & $95^{\circ} \mathrm{C}$ & $2.91 \pm 0.23$ & $2.25 \pm 0.20$ \\
$\begin{array}{c}\text { G. stearothermophilus } \\
\text { CIP-23T }\end{array}$ & $125^{\circ} \mathrm{C}$ & $10.06 \pm 0.45$ & $8.46 \pm 0.43$ \\
$\begin{array}{c}\text { C. sporogenes pasteur } \\
\text { 79.3 }\end{array}$ & $90^{\circ} \mathrm{C}$ & $12.59 \pm 0.95$ & $7.47 \pm 0.28$ \\
\begin{tabular}{c} 
C. sporogenes 81 \\
\hline
\end{tabular} & $90^{\circ} \mathrm{C}$ & $15.63 \pm 2.25$ & $13.4 \pm 1.90$ \\
\hline
\end{tabular}

${ }^{*} \mathrm{D}$ values $\pm \mathrm{CI} 95 \%$.

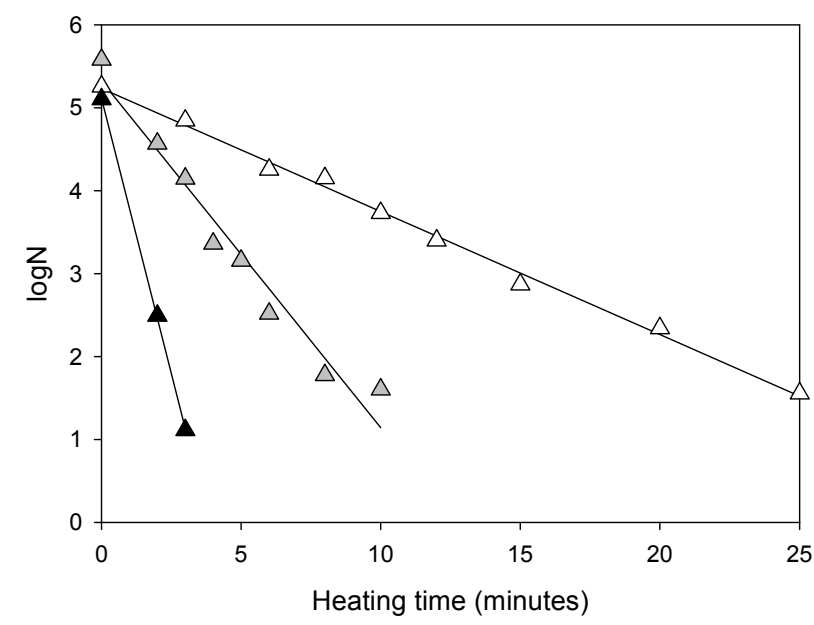

Figure 1. $\log \mathrm{N}$ versus heating time for Bacillus cereus ATCC 11145 corresponding to different oleic acid concentrations in recovery media: $0.0 \mathrm{mmol} \cdot \mathrm{l}^{-1} \triangle, 0.4 \mathrm{mmol} \cdot \mathrm{l}^{-1} \Delta$, $0.8 \mathrm{mmol} \cdot \mathrm{I}^{-1} \Delta$. 
Table 2. D values (minutes) determined for different species of bacterial spores for different molarities of oleic acid added to recovery media and associated $\mathbf{z}_{\mathrm{C} 18: 1}^{\prime}$ parameters.

\begin{tabular}{cccccccc}
\hline & Heating T ${ }^{\circ} \mathrm{C}$ & $0.0 \mathrm{mmol} \cdot \mathrm{l}^{-1}$ & $0.2 \mathrm{mmol} \cdot \mathrm{l}^{-1}$ & $0.4 \mathrm{mmol} \cdot \mathrm{l}^{-1}$ & $0.6 \mathrm{mmol} \cdot \mathrm{l}^{-1}$ & $0.8 \mathrm{mmol} \cdot \mathrm{l}^{-1}$ & $\mathrm{z}_{\mathrm{C} 18 \mathrm{1}}^{\prime} \mathrm{mmol} \cdot \mathrm{l}^{-1}$ \\
\hline B. cereus ATCC 11145 & $100^{\circ} \mathrm{C}$ & $6.74 \pm 0.20$ & $3.38 \pm 0.35$ & $2.39 \pm 0.24$ & $1.45 \pm 0.67$ & $0.75 \pm 0.06$ & $0.89 \pm 0.13$ \\
B. pumilus $\mathrm{E} 71$ & $95^{\circ} \mathrm{C}$ & $2.12 \pm 0.23$ & $1.00 \pm 0.27$ & $0.58 \pm 0.20$ & $\mathrm{ND}$ & $0.45 \pm 0.18$ & $1.52 \pm 0.62$ \\
B. licheniformis BAC37 & $85^{\circ} \mathrm{C}$ & $10.75 \pm 0.03$ & $8.81 \pm 0.28$ & $7.56 \pm 0.17$ & $6.39 \pm 0.08$ & $5.69 \pm 0.35$ & $3.16 \pm 0.31$ \\
G. stearothermophilus CIP-23T & $120^{\circ} \mathrm{C}$ & $3.40 \pm 2.25$ & $4.10 \pm 2.25$ & $2.00 \pm 0.9$ & $1.80 \pm 0.4$ & $\mathrm{ND}$ & $1.78 \pm 3.47$ \\
C. sporogenes Pasteur 79.3 & $90^{\circ} \mathrm{C}$ & $11.31 \pm 0.21$ & $2.30 \pm 0.72$ & $0.59 \pm 0.5 \mathrm{I}$ & $\mathrm{ND}$ & $\mathrm{ND}$ & $0.31 \pm 0.1$ \\
C. sporogenes 81 & $90^{\circ} \mathrm{C}$ & $15.6 \pm 2.25$ & $7.2 \pm 2.3$ & $5.9 \pm 0.9$ & $2.80 \pm 0.4$ & $1.62 \pm 0.3$ & $0.84 \pm 0.22$ \\
\hline
\end{tabular}

^ND: Not Determined; ${ }^{*} \mathrm{D}$ values \pm CI $95 \%$.

Table 3. $D_{100}{ }^{\circ} \mathrm{C}$ values (minutes) determined for $B$. cereus ATCC 11145 for $0.0 \mathrm{mmol} \cdot \mathrm{I}^{-1}$ and $0.8 \mathrm{mmol} \cdot \mathrm{I}^{-1}$ of free fatty acids with different chain lengths added to heating media.

\begin{tabular}{ccc}
\hline & $0.0 \mathrm{mmol} \cdot \mathrm{l}^{-1}$ & $0.8 \mathrm{mmol} \cdot \mathrm{l}^{-1}$ \\
\hline $\mathrm{C} 14: 0$ & $7.02 \pm 0.70^{*}$ & $2.98 \pm 0.27$ \\
$\mathrm{C} 16: 0$ & $6.74 \pm 0.41$ & $5.61 \pm 0.35$ \\
$\mathrm{C} 18: 0$ & $6.99 \pm 0.20$ & $5.54 \pm 0.43$ \\
$\mathrm{C} 20: 0$ & $6.67 \pm 0.03$ & $5.74 \pm 0.21$ \\
\hline
\end{tabular}

${ }^{*}$ D values \pm CI $95 \%$.

Table 4. $D_{100^{\circ} \mathrm{C}}$ values (minutes) determined for $B$. cereus ATCC 11145 for different molarities of free fatty acids with different chain lengths added to recovery media.

\begin{tabular}{ccccccc}
\hline & $0.0 \mathrm{mmol} \cdot 1^{-1}$ & $0.2 \mathrm{mmol} \cdot 1^{-1}$ & $0.4 \mathrm{mmol} \cdot 1^{-1}$ & $0.6 \mathrm{mmol} \cdot \mathrm{l}^{-1}$ & $0.8 \mathrm{mmol} \cdot 1^{-1}$ & $\mathrm{Z}_{\mathrm{FFA}}^{\prime} \mathrm{mmol} \cdot 1^{-1}$ \\
\hline $\mathrm{C} 14: 0$ & $7.02 \pm 0.70$ & $5.78 \pm 0.59$ & $4.80 \pm 0.34$ & $4.13 \pm 0.35$ & $\mathrm{ND}$ & $2.70 \pm 0.81$ \\
$\mathrm{C} 16: 0$ & $7.40 \pm 0.41$ & $\mathrm{ND}$ & $6.57 \pm 0.21$ & $\mathrm{ND}$ & $3.78 \pm 0.34$ & $5.01 \pm 1.06$ \\
$\mathrm{C} 18: 0$ & $6.78 \pm 1.03$ & $4.63 \pm 0.34$ & $3.99 \pm 0.27$ & $3.26 \pm 0.27$ & $2.68 \pm 0.16$ & $3.19 \pm 0.83$ \\
$\mathrm{C} 20: 0$ & $6.67 \pm 0.31$ & $6.11 \pm 0.28$ & $5.55 \pm 0.19$ & $5.30 \pm 0.21$ & $4.84 \pm 0.21$ & $5.90 \pm 0.51$ \\
\hline
\end{tabular}

ND: Not Determined; ${ }^{*}$ D values \pm CI $95 \%$.

fatty acid concentration for four different carbon chain length fatty acids (C14:0, C16:0, C18:0, C20:0). Regarding the influence of the chain length of free fatty acids added to heating media on the heat resistance of Bacillus cereus, the addition of $0.8 \mathrm{mmol} \cdot \mathrm{l}^{-1}$ of myristic acid (C14:0) reduces the D value by 2.35 fold. Concerning the influence of saturated free fatty acids added to recovery media, $\mathrm{z}_{\mathrm{FFA}}^{\prime}$ values indicate that the thermal resistance of Bacillus cereus is more greatly reduced with the addition of myristic acid (C14:0) or stearic acid (C18:0) than palmitic acid (C16:0) or arachidonic acid $(\mathrm{C} 20: 0)$ in the recovery media. These results show that no correlation appears between $\mathrm{D}$ or $\mathrm{z}_{\mathrm{FFA}}^{\prime}$ values and the length of the carbon chain of the saturated free fatty acid.

The influence of the degree of unsaturation of the carbon chains of free fatty acids added to heating and re- covery media on the heat resistance of bacterial spores was investigated for free fatty acids with a length of 18 carbons: stearic (C18:0), oleic (C18:1), linoleic (C18:2) and linolenic (C18:3) acid on 3 different bacterial species: Bacillus cereus, Bacillus pumilus and Clostridium sporogenes (Tables 5 and $\mathbf{6}$ ). The addition of $\mathrm{C} 18$ free fatty acid to the heat treatment media slightly reduced the heat resistance of bacterial spores, whatever their degree of unsaturation. On the other hand, the addition of unsaturated free fatty acids to the recovery medium reduced the heat resistance of bacterial spores to a greater extent than saturated acids (Figure 2).

For the strains Bacillus cereus and Bacillus pumilus, the influence of linolenic acid (C18:3), added to the recovery media, reduced the apparent heat resistance of spores respectively nine and seven fold, compared to the 
Table 5. D values (minutes) determined for $0 \mathrm{mmol} \cdot \mathrm{l}^{-1}$ and $0.8 \mathrm{mmol} \cdot \mathrm{I}^{-1}$ of free fatty acids with different unsaturated bond numbers added to heating media.

\begin{tabular}{cccc}
\hline & & $0.0 \mathrm{mmol} \cdot \mathrm{l}^{-1}$ & $0.8 \mathrm{mmol} \cdot \mathrm{l}^{-1}$ \\
\hline $\begin{array}{c}\text { B. cereus } \\
\text { ATCC 11145 }\end{array}$ & $\mathrm{C} 18: 0$ & $6.74 \pm 0.20^{*}$ & $5.21 \pm 0.35$ \\
$100^{\circ} \mathrm{C}$ & $\mathrm{C} 18: 1$ & $6.74 \pm 0.20$ & $4.77 \pm 0.28$ \\
& $\mathrm{C} 18: 2$ & $6.33 \pm 0.34$ & $5.37 \pm 0.16$ \\
& $\mathrm{C} 18: 3$ & $6.33 \pm 0.68$ & $3.46 \pm 0.78$ \\
& $\mathrm{C} 18: 0$ & $2.88 \pm 0.24$ & $2.27 \pm 0.17$ \\
B. pumilus $\mathrm{E} 71$ & $\mathrm{C} 18: 1$ & $2.91 \pm 0.22$ & $2.25 \pm 0.20$ \\
& $\mathrm{C} 18: 2$ & $2.91 \pm 0.22$ & $2.48 \pm 0.15$ \\
$95^{\circ} \mathrm{C}$ & $\mathrm{C} 18: 3$ & $2.91 \pm 0.21$ & $2.18 \pm 0.20$ \\
& $\mathrm{C} 18: 0$ & $12.72 \pm 2.04$ & $12.12 \pm 0.63$ \\
C. sporogenes & $\mathrm{C} 18: 1$ & $11.31 \pm 0.21$ & $7.47 \pm 0.28$ \\
pasteur 79.3 & $\mathrm{C} 18: 2$ & $11.31 \pm 0.21$ & $11.70 \pm 1.28$ \\
& $\mathrm{C} 18: 3$ & $12.18 \pm 0.79$ & $13.33 \pm 0.94$ \\
\hline
\end{tabular}

-ND: not determined; " D values \pm CI $95 \%$.

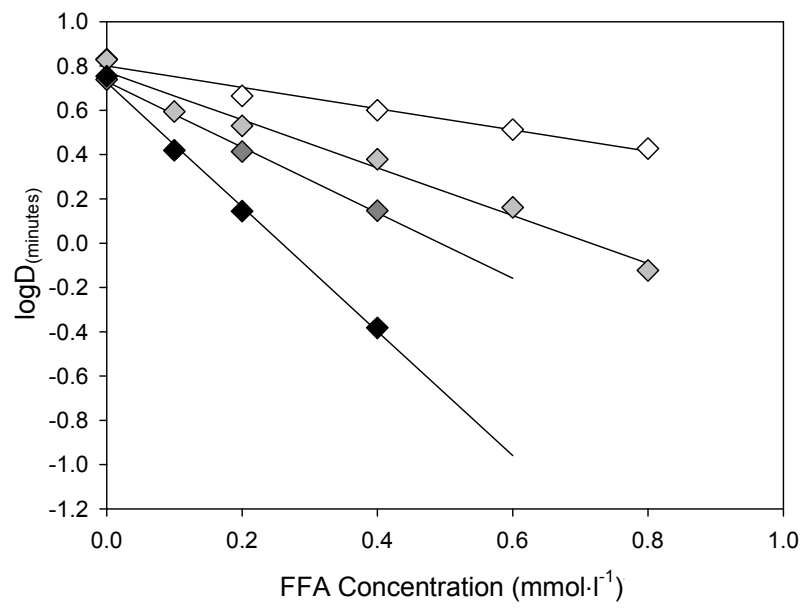

Figure 2. $\log D$ versus concentration of free fatty acid for Bacillus cereus ATCC 11145 corresponding to different unsaturated bond numbers in recovery media: C18:0 $\diamond$, C18:1 , C18:2 $\diamond$, C18:3 $\diamond$.

addition of stearic acid (C18:0) (Table 6). For Clostridium sporogenes, the addition of unsaturated free fatty acid greatly reduced the $\mathrm{z}_{\mathrm{FFA}}^{\prime}$ values to the same extent, regardless of the degree of unsaturation. The $\mathrm{z}_{\mathrm{FFA}}^{\prime}$ value decreased from $2.36 \mathrm{mmol} \cdot \mathrm{l}^{-1}$ for stearic acid to 0.36 $\mathrm{mmol} \cdot \mathrm{l}^{-1}$ for oleic acid. For the 3 species studied, the low values of $z_{\mathrm{FFA}}^{\prime}$ parameters of unsaturated free fatty acids characterized their high impact.

\section{Discussion}

The presence of free fatty acids in the heating media at a concentration of $0.8 \mathrm{mmol} \cdot \mathrm{l}^{-1}$ globally reduces bacterial spore heat resistance. This result is in agreement with the work of Tremoulet et al. [22], who observed a 75 percent reduction of the $\mathrm{D}$ value by adding $0.6 \mathrm{mmol} \cdot \mathrm{l}^{-1}$ of oleic acid to the heating media. However adding free fatty acid to the recovery media after heat treatment greatly reduces the apparent heat resistance of bacterial spores. It can be noted that these concentrations in media are lower than those found in some foods [26].

It is well recognized that the influence of unfavorable environmental factors during recovery strongly affects the apparent heat resistance of microorganisms. When environmental recovery factors deviate from optimal growth conditions, the apparent heat resistance of microorganisms decreases. The bactericidal effects of free fatty acids are well known $[6,19,27]$. Concentrations of free fatty acid below the critical micelle concentrations have a stressful effect on vegetative cells and bacterial spores. When added to recovery media, this stressful effect reduces the apparent heat resistance of bacterial spores [23, 24].

As no other parameter values of sensitivity $\left(\mathrm{z}_{\mathrm{FFA}}^{\prime}\right)$ are available in the literature, it may be interesting to compare the $z_{\mathrm{FFA}}^{\prime}$ sensitivity data to the minimum inhibitory concentration (MIC) presented in Table 7. Concerning bacterial spores, MIC values quantify the inhibition effect of free fatty acid both on spore germination and vegetative bacterial growth. Few data exist indicating the MIC of free fatty acids; however these few data show variability between species studied. For Clostridium perfringens, MIC values for oleic acid range from 2.4 $\mathrm{mmol} \cdot \mathrm{l}^{-1}$ to $10.2 \mathrm{mmol} \cdot \mathrm{l}^{-1}[15,28]$. The MIC value is $0.75 \mathrm{mmol} \cdot \mathrm{l}^{-1}$ for Geobacillus stearothermophilus [22] and $0.05 \mathrm{mmol} \cdot \mathrm{l}^{-1}$ for Bacillus megaterium [29]. Similar observations can be made for the inhibitory effect of fatty acids for one part on no heated bacterial spores characterized by the MIC values and on the other part on heated bacterial spores quantified by the sensitivity parameter $\mathrm{z}_{\mathrm{FFA}}^{\prime}$. A link can be noted between their MIC values and the $\mathrm{z}_{\mathrm{FFA}}^{\prime}$ sensitivity parameter values. For the strain of Bacillus cereus studied, our results show that no relationship appears between sensitivity parameter values associated to the acids studied and the length of their carbon chain. A similar observation can be made concerning the evolution of MIC values according to chain length between 12 and 18 carbons (Table 7). It should be noted that for palmitic and stearic acids, MIC values appear to be higher than $10 \mathrm{mmol} \cdot \mathrm{l}^{-1}$, except for Bacillus megaterium [29].

Our results show that for heat-treated Bacillus cereus, Bacillus pumilus and Clostridium sporogenes spores, the higher the number of unsaturated bonds in the carbon chain, the more sensitive the spores are to the free fatty acid: linoleic acid $>$ oleic acid $>$ stearic acid. These ob- 
Table 6. D values (minutes) determined for different molarities of free fatty acids with different unsaturated bond numbers added to recovery media.

\begin{tabular}{|c|c|c|c|c|c|c|c|}
\hline & & $0.0 \mathrm{mmol} \cdot \mathrm{l}^{-1}$ & $0.2 \mathrm{mmol} \cdot 1^{-1}$ & $0.4 \mathrm{mmol} \cdot \mathrm{l}^{-1}$ & $0.6 \mathrm{mmol} \cdot 1^{-1}$ & $0.8 \mathrm{mmol} \cdot 1^{-1}$ & $\mathrm{z}_{\mathrm{FFA}}^{\prime} \mathrm{mmol} \cdot \mathrm{l}^{-1}$ \\
\hline \multirow{2}{*}{$\begin{array}{c}\text { B. cereus } \\
\text { ATCC } 11145\end{array}$} & $\mathrm{C} 18: 0$ & $4.62 \pm 0.47^{*}$ & $4.63 \pm 0.34$ & $3.99 \pm 0.27$ & $3.26 \pm 0.27$ & $2.68 \pm 0.16$ & $3.19 \pm 0.83$ \\
\hline & $\mathrm{C} 18: 1$ & $6.74 \pm 0.71$ & $3.38 \pm 0.35$ & $2.39 \pm 0.24$ & $1.45 \pm 0.67$ & $0.75 \pm 0.06$ & $0.89 \pm 0.65$ \\
\hline \multirow[t]{2}{*}{$100^{\circ} \mathrm{C}$} & $\mathrm{C} 18: 2$ & $6.33 \pm 0.34$ & $3.03 \pm 0.36$ & $1.40 \pm 0.79$ & $\mathrm{ND}^{\star}$ & ND & $0.61 \pm 0.04$ \\
\hline & $\mathrm{C} 18: 3$ & $5.68 \pm 1.14$ & $1.39 \pm 0.32$ & $0.42 \pm 0.12$ & ND & ND & $0.36 \pm 0.03$ \\
\hline \multirow{2}{*}{ B. pumilus E71 } & C18:0 & $2.23 \pm 0.47$ & $1.29 \pm 0.29$ & $1.99 \pm 0.35$ & $1.93 \pm 0.34$ & ND & $3.53 \pm 0.97$ \\
\hline & C18:1 & $2.12 \pm 0.23$ & $1.00 \pm 0.27$ & $0.58 \pm 0.20$ & ND & ND & $1.25 \pm 0.31$ \\
\hline \multirow[t]{2}{*}{$95^{\circ} \mathrm{C}$} & $\mathrm{C} 18: 2$ & $2.26 \pm 0.16$ & $1.59 \pm 0.30$ & $0.56 \pm 0.04$ & $0.28 \pm 0.08$ & ND & $0.67 \pm 0.15$ \\
\hline & $\mathrm{C} 18: 3$ & $2.30 \pm 0.23$ & $0.93 \pm 0.11$ & ND & ND & ND & $0.51 \pm 0.09$ \\
\hline \multirow{2}{*}{$\begin{array}{c}\text { C. sporogenes } \\
\text { pasteur } 79.3\end{array}$} & $\mathrm{C} 18: 0$ & $12.72 \pm 1.89$ & $10.81 \pm 0.77$ & $7.09 \pm 0.80$ & $6.88 \pm 1.55$ & $6.01 \pm 0.83$ & $2.36 \pm 0.66$ \\
\hline & C18:1 & $11.31 \pm 0.21$ & $2.30 \pm 0.72$ & $0.59 \pm 0.52$ & ND & ND & $0.36 \pm 0.05$ \\
\hline \multirow[t]{2}{*}{$90^{\circ} \mathrm{C}$} & $\mathrm{C} 18: 2$ & $11.31 \pm 0.21$ & $1.60 \pm 0.32$ & ND & ND & ND & $0.40 \pm 0.04$ \\
\hline & $\mathrm{C} 18: 3$ & $12.18 \pm 0.79$ & $4.36 \pm 0.48$ & $3.14 \pm 0.01$ & $0.67 \pm 0.07$ & ND & $0.52 \pm 0.08$ \\
\hline
\end{tabular}

ND: not determined; ${ }^{*}$ D values \pm C.I. $95 \%$.

Table 7. Minimum Inhibitory Concentration $\left(\mathrm{mmol}^{-l^{-1}}\right)$ of $\mathrm{C10}-\mathrm{C18}$ fatty acids on spore-forming bacteria referred to previous references.

\begin{tabular}{|c|c|c|c|c|c|c|c|c|c|c|}
\hline & & $\mathrm{C} 10: 0$ & $\mathrm{C} 12: 0$ & $\mathrm{C} 14: 0$ & $\mathrm{C} 16: 0$ & $\mathrm{C} 16: 1$ & $\mathrm{C} 18: 0$ & $\mathrm{C} 18: 1$ & $\mathrm{C} 18: 2$ & $\mathrm{C} 18: 3$ \\
\hline G. stearothermophilus ATCC7953 & {$[22]$} & & & & $>10$ & 1.25 & $>10$ & 0.75 & 0.01 & \\
\hline B. megaterium NCIB9521 & [29] & 1.00 & 0.15 & 0.15 & 0.30 & & 0.40 & 0.05 & 0.02 & 0.02 \\
\hline C. perfringens CCM4435 & [15] & & 0.20 & 0.40 & $>19.5$ & & $>17.5$ & 2.40 & $>17.5$ & \\
\hline C. perfringens CNCTC 5459 & {$[15]$} & & 0.20 & 0.90 & $>19.5$ & & $>17.5$ & 7.39 & 2.40 & \\
\hline C. perfringens Type A (pH6.5) & {$[28]$} & 9.98 & 49.92 & 99.84 & $>100$ & & $>100$ & 10.02 & 0.20 & 1.00 \\
\hline C. perfringens Type A (pH7.5) & {$[28]$} & 50.04 & 9.98 & 20.01 & $>100$ & & $>100$ & 10.02 & 0.20 & 1.00 \\
\hline
\end{tabular}

servations may be related to the evolution of MIC values for these acids applied to different bacterial species (Table 7). It is clear that bacteria or bacterial spores affected by heat treatments are very sensitive to an additive stress such as free fatty acids in recovery media. During heat treatment, the rates of activated or injured spores increased with heating time. The antimicrobial effect of free fatty acid according to their characteristics, chain length or bond number on heat-injured spores are similar and amplified compared to their effect on uninjured spores. The presence of free acids in the recovery media after heat treatment is a second stress which decreases the capability of injured spores to germinate and grow thereafter.

Under laboratory conditions, in media in which free fatty acids are scattered using Tween ${ }^{\mathrm{TM}}$ 80, high mixing and ultrasound, a low level of free fatty acid concentrations presents an important bactericidal effect on heat stressed spores. The natural occurrence of free fatty acids in some foods and oils is higher than the concentration studied. The impact of free fatty acid can be taken into account to reduce the thermal intensity of food sterilization if these effects can be verified in heat-treated foods.

\section{REFERENCES}

[1] L. Leistner, "Basic Aspects of Food Preservation by Hurdle Technology," International Journal of Food Microbiology, Vol. 55, No. 1, 2000, pp. 181-186. doi:10.1016/S0168-1605(00)00161-6

[2] O. Cerf, K. Davey and A. Sadoudi, "Thermal Inactivation of Bacteria: A New Predictive Model for the Combined Effects of Temperature, $\mathrm{pH}$ and Water Activity," Food Research International, Vol. 299, No. 3-4, 1996, pp. 219-226. doi:10.1016/0963-9969(96)00039-7

[3] O. Couvert, I. Leguérinel and P. Mafart, "Modelling the Overall Effect of $\mathrm{pH}$ on the Apparent Heat Resistance of 
Bacillus cereus Spores," International Journal of Food Microbiology, Vol. 49, No. 1-2, 1999, pp. 57-62. doi:10.1016/S0168-1605(99)00052-5

[4] P. Mafart, I. Leguérinel, O. Couvert and L. Coroller, "Quantification of Spore Resistance for Assessment and Optimization of Heating Processes: A Never-Ending Story," Food Microbiology, Vol. 27, No. 5, 2010, pp. 568-572. doi:10.1016/j.fm.2010.03.002

[5] C. Nieman, "Influence of Trace Amounts of Fatty Acids on the Growth of Microorganisms," Bacteriology Reviews, Vol. 18, No. 2, 1954, pp. 147-163.

[6] J. J. Kabara, "Fatty Acids and Derivatives as Antimicrobial Agents. A Review," In: J. J. Kabara, Ed., The Pharmacological Effect of Lipids, Vol. 1, American Oil Chemists Society, Champaign, 1978, pp. 1-14.

[7] E. Skřivanova, O. G. Savka and M. Marounek, "In Vitro Effect of C2-C18 Fatty Acids on Salmonellas," Folia Microbiologica, Vol. 48, No. 2, 2004, pp. 199-202. doi:10.1007/BF02931402

[8] J. Y. Lee, Y. S. Kim and D. H. Shin, "Antimicrobial Synergistic Effect of Linolenic Acid and Monoglyceride against Bacillus cereus and Staphylococcus aureus," Journal of Agricultural and Food Chemistry, Vol. 50, No. 7, 2002, pp. 2193-2199. doi:10.1021/jf011175a

[9] M. Denton, S. Dealler, D. Birkenhead and R. Lacey, "Inhibition of Listeria by Unsaturated Fatty Acids," Journal of Nutritional and Environmental Medicine, Vol. 2, No. 4, 1991, pp. 383-386. doi:10.3109/13590849109084141

[10] M. Marounek, E. Skřivanova and V. Rada, "Susceptibility of Escherichia coli to C2-C18 Fatty Acids," Folia Microbiologica, Vol. 48, No. 6, 2003, pp. 731-735. doi:10.1007/BF02931506

[11] C. Altieri, A. Bevilacqua, D. Cardillo and M. Sinigaglia, "Effectiveness of Fatty Acids and their Monoglycerides against Gram-Negative Pathogens," International Journal of Food Science \& Technology, Vol. 44, No. 2, 2009, pp. 359-366. doi:10.1111/j.1365-2621.2008.01744.x

[12] L. Ababouch, A. Chaibi and F. F. Busta, "Inhibition of Bacterial Spore Growth by Fatty Acids and Their Sodium Salts," Journal of Food Protection, Vol. 55, No. 12, 1992, pp. 980-984.

[13] T. Tsuchido, S. Naruki and I. Shibasaki, "Inhibition of Bacillus subtilis var. Niger Spores by Fatty Acids and their Monoglycerides," Journal of Antibacterial and Antifungal Agents, Vol. 20, No. 1, 1992, pp. 197-203.

[14] N. Grecz, R. O. Wagenar and C. M. Dack, "Relation of Fatty Acids to Inhibition of Clostridium botulinum in Aged Surface Ripened Cheese," Applied Microbiology, Vol. 7, No. 4, 1959, pp. 228-234.

[15] E. Skřivanova, M. Marounek, G. Dlouhá and J. Kañka, "Susceptibility of Clostridium Perfringens to C2-C18 Fatty Acids," Letters in Applied Microbiology, Vol. 41, No. 1, 2005, pp. 77-81. doi:10.1111/j.1472-765X.2005.01709.x

[16] J. W. Foster and E. S. Wynne, "Physical Studies on Spore Germination, with Special Reference to Clostridium botulinum, IV Inhibition of Germination by Unsaturated C18 Fatty Acids," Journal of Bacteriology, Vol. 55, No. 4,
1948, pp. 495-504.

[17] Y. Yasuda, K. Tochikubo, Y. Hachisuka, H. Tomida and K. Ikeda, "Quantitative Structure-Inhibitory Activity Relationships of Phenols and Fatty Acids for Bacillus subtilis Spore Germination," Journal of Medicinal Chemistry, Vol. 25, No. 3, 1982, pp. 315-320.

doi: $10.1021 / \mathrm{jm} 00345 \mathrm{a} 016$

[18] K. Johnstone, "The trigger Mechanism of Spore Germination: Current Concepts," Journal of Applied Microbiology, Vol. 76, No. S23, 1994, pp. 17S-24S. doi:10.1111/j.1365-2672.1994.tb04354.x

[19] A. Desbois and V. Smith, “Antibacterial Free Fatty Acids: Activities, Mechanisms of Action and Biotechnological Potential," Applied Microbiology and Biotechnology, Vol. 85, No. 6, pp. 1629-1642.

[20] R. B. Maxcy and C. W. Dill, "Adsorption of Free Fatty Acids on Cells of Certain Microorganisms," Journal of Dairy Sciences, Vol. 50, No. 4, 1967, pp. 472-476. doi:10.3168/jds.S0022-0302(67)87449-6

[21] H. Galbraith and T. B. Miller "Effect of Long Chain Fatty Acids on Bacterial Respiration and Amino Acid Uptake," Journal of Applied Bacteriology, Vol. 36, No. 4, 1973, pp. 4659-4675.

[22] F. Tremoulet, P. Rabier and G. Gas, "Inhibition of Bacillus stearothermophilus Spores in Liquid Medium by Free Fatty Acids with and without Heat: Possible Mechanism for the Microbiological Stability of Canned Fat-Duck Liver," Journal of Food Science, Vol. 67, No. 4, 2002, pp. 1144-1148. doi:10.1111/j.1365-2621.2002.tb09467.x

[23] H. L. Ababouch, F. Bouquartacha, and F. F. Busta, "Inhibition of Bacillus cereus Spores and Vegetative Cells by Fatty Acids and Glyceryl Monododecanoate," Food Microbiology, Vol. 11, No. 4, 1994, pp. 327-336. doi:10.1006/fmic.1994.1037

[24] B. Mvou Lekogo, L. Coroller, A. G. Mathot, P. Mafart and I. Leguerinel, "Modelling the Influence of Palmitic, Palmitoleic, Stearic and Oleic Acids on Apparent Heat Resistance of Spores of Bacillus cereus NTCC 11145 and Clostridium sporogenes Pasteur 79.3," International Journal of Food Microbiology, Vol. 141, No. 3, 2010, pp. 242-247. doi:10.1016/j.ijfoodmicro.2010.05.023

[25] J. S. Goldoni, S. Kojima, S. Leonard and J. R. Heil, "Growing Spores of P. A. 3679 in Formulations of Beef Heart Infusion Broth,” Journal of Food Science, Vol. 45, No. 3, 1980, pp. 467-470. doi:10.1111/j.1365-2621.1980.tb04077.x

[26] N. O. V. Sonntag, "Composition and Characteristics of Individual Fats and Oils". In: D. Swern, Ed., Bailey's Industrial Oil and Fat Products, 4th Edition, Vol. 1, WileyInterscience, New-York, 1979, pp. 289-477.

[27] J. J. Kabara, D. M. Swieczkowski, A. J. Conley and J. P. Truant, "Fatty Acids and Derivatives as Antimicrobial Agents," Antimicrobial Agents Chemotherapy, Vol. 2, No. 1, 1972, pp. 23-28. doi:10.1128/AAC.2.1.23

[28] R. Fuller and J. H. Moore, "The Inhibition of the Growth of Clostridium welchii by Lipids Isolated from the Contents of the Small Intestine of the Pig," Microbiology, Vol. 46, No. 1, 1967, pp. 23-41. 
[29] H. Galbraith, T. B. Miller, A. M. Paton and J. K. Thompson, "Antibacterial Activity of Long Chain Fatty Acids and the Reversal with Calcium, Magnesium, Ergocalcif- erol and Cholesterol," Journal of Applied Microbiology, Vol. 34, No. 4, 1971, pp. 803-813. 